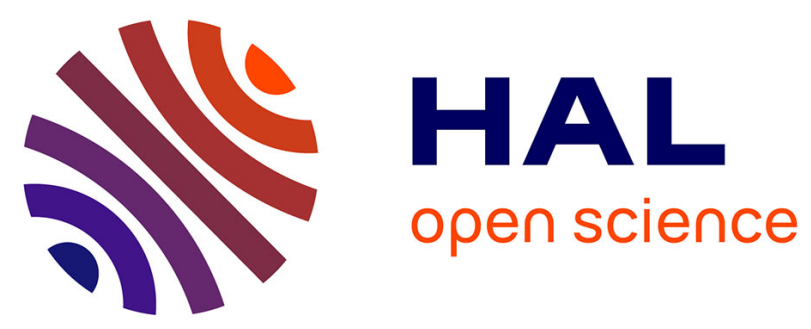

\title{
HEREDITARY LEGAL SUCCESSION IN THE CIVIL LAW OF UKRAINE: PROBLEMATIC AND THEORETICAL ASPECT
}

Anatoliy Kostruba

\section{- To cite this version:}

Anatoliy Kostruba. HEREDITARY LEGAL SUCCESSION IN THE CIVIL LAW OF UKRAINE: PROBLEMATIC AND THEORETICAL ASPECT. Journal of the National Academy of Legal Sciences of Ukraine, 2019, 26 (3), pp.135-149. 10.31359/1993-0909-2019-26-3-161 . hal-02411634

\author{
HAL Id: hal-02411634 \\ https://hal.science/hal-02411634
}

Submitted on 18 Dec 2019

HAL is a multi-disciplinary open access archive for the deposit and dissemination of scientific research documents, whether they are published or not. The documents may come from teaching and research institutions in France or abroad, or from public or private research centers.
L'archive ouverte pluridisciplinaire HAL, est destinée au dépôt et à la diffusion de documents scientifiques de niveau recherche, publiés ou non, émanant des établissements d'enseignement et de recherche français ou étrangers, des laboratoires publics ou privés. 
УДК 347.674(477)

DOI: 10.31359/1993-0909-2019-26-3-161

\author{
Анатолій Володимирович Коструба \\ Кафедра ииивільного права \\ Прикарпатський наиіональний університет \\ імені Василя Стефаника

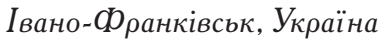

\title{
СПАДКОВЕ ПРАВОНАСТУПНИЦТВО В ЦИВІЛЬНОМУ ПРАВІ УКРАЇНИ: ПРОБЛЕМНО-ТЕОРЕТИЧНИЙ АСПЕКТ
}

\begin{abstract}
Анотація. Інститут спадкування є складною системою конструкиій. Залежно від способу організації та побудови иүілого із складових частин спостерігаються різні варіації конструювання спадкового правонаступництва. У свою чергу, сучасні сочіально-економічні умови значно прискорюють життєвий циклл людини, щчо привертає підвищену увагу до його прав і обов'язків, які перейдуть в порядку правонаступництва до інших осіб - спадкоємиів. Тому основна мета роботи полягає в проведенні комплексного дослідження інституту спадкового правонаступництва в циивільному праві Украӥни крізь призму теоретично обтрунтованої проблематики в контексті якісних трансформацій відповідних правовідносин та їх правового регулювання. Для досягнення поставленої мети автором були використані закони та категорії діалектики, формально-логічні прийоми, засоби герменевтики. Загальну методологічну основу статті склав діалектичний метод пізнання. В результаті дослідження автором констатовано обмеження ролі сімейно-забезпечувальної функиії в спадковому праві Украӥни і розвиток в ньому концепції сингулярного правонаступництва. Автором обгрунтовано висновок про те, щзо правонаступниитво окремих об'єктів цฺивільного права або взагалі не підлягає ичивільно-правовому регулюванню, або підтверджує, щзо спадковому праву притаманний сингулярних характер успадкування об'єктів циивільного права. Автором також проведено дослідження універсального і сингулярного спадкового правонаступниитва через призму їх генезису від правового регулювання часів Стародавнього Риму до сьогодні. В результаті комплексного аналізу були окреслені провідні проблеми в сфері спадкового правонаступництва в ичивільному праві Украӥни, які вимагають свого поступового i зваженого рішення шляхом консолідації зусиль представників доктрини і практики з метою уніфікачії, поновлення, $і$ як підсумок - якісного реформування правового регулювання інституту спадкового правонаступництва в Украӥні в контексті позитивного досвіду інших держав та його поступової апробаџії на наџіональному рівні.
\end{abstract}

Ключові слова: спадкове право, сингулярне правонаступництво, спадкодавець, заповідальний відказ, цивільне право. 
Anatoly V. Kostruba

Department of Civil Law

Vasyl Stefanyk $\rho_{\text {recarpathian National University }}$

Ivano-Frankivsk, Ukraine

\title{
HEREDITARY LEGAL SUCCESSION \\ IN THE CIVIL LAW OF UKRAINE: \\ PROBLEMATIC AND THEORETICAL ASPECT
}

\begin{abstract}
The institution of succession is a complex system of constructs. Depending on the method of organization and construction of the whole from the constituent parts, different variations of the design of hereditary legal succession are observed. In turn, modern socioeconomic conditions significantly accelerate a person's life cycle, which draws increased attention to their rights and obligations, which will be transferred by legal succession to other persons - heirs. Therefore, the main goal of the article is to conduct a comprehensive study of the institution of succession in the civil law of Ukraine through the lens of theoretically substantiated issues in the context of the qualitative transformations of the relevant legal relations and their legal regulation. To achieve this goal, the author used the laws and categories of dialectics, formal and logical techniques, means of hermeneutics. The general methodological basis of the article was the dialectical method of cognition. As a result of the study, the author ascertained the limitation of the role of the family support function in the succession law of Ukraine and the development of the concept of a singular succession therein. The author substantiates the conclusion that the legal succession of certain objects of civil law is either not subject to civil law regulation at all, or confirms that the singular nature of inheritance of objects of civil law is inherent in succession law. The author also performed a research of universal and singular succession through the lens of their genesis from legal regulation of the times of Ancient Rome to today. As a result of a comprehensive analysis, the most pressing issues in the field of succession in civil law of Ukraine were outlined, which require their gradual and balanced solution by consolidating the efforts of representatives of the doctrine and practice in order to unify, update, and as a result-qualitatively reform the legal regulation of the institution of hereditary legal succession in Ukraine in the context of the positive experience of other states and its gradual testing at the national level.
\end{abstract}

Keywords: succession law, singular succession, testator, testamentary gift, civil law.

\section{INTRODUCTION}

Civil legal succession, as the transfer of rights and obligations from one person to another, occurs in the obligation and property law relations. A special type of civil legal succession is hereditary legal succession, which involves the transfer of subjective civil rights and obligations from a deceased person to another person, or to persons on the basis of the legal provisions on succession. The institution of inheritance ensures the transfer of the rights and duties of a deceased citizen, or who is declared dead in the manner prescribed by law, due to an unknown absence, to other persons specified by law [1]. The complexity of the institution of inheritance succes- 
sion, connected with the transfer of property, as well as the rights and obligations of the legal successor to the legal successor in the actual and legal preservation of legal relations that existed under the legal successor, determines the multitude of theoretical approaches to determine its legal nature.

Thus, at present, the concept of the universal hereditary legal succession remains dominant (B.B. Cherepakhin [1], V.I. Serebrovsky [2], B.S. Antimonov [3], etc.). Its main provisions boil down to the fact that the hereditary mass is an inseparable unity of the rights and obligations of the testator and passes to one or more heirs as a whole without first transferring them as an intermediate stage to any person, i.e. directly [4-7].

Thus, its supporters conclude that not every transfer of subjective civil rights and obligations after the death of the legal successor should be considered as a hereditary legal succession. The historical and legal prerequisite for the formation of the concept of universal succession was the emergence of a new social organism, the head of which was the master of his wife and children, as well as a certain number of slaves, possessing, by virtue of Roman paternal authority, the right to control the life and death of all his subordinates ("pater familias"). This approach stemmed from the entire system of the Roman family as a closed socio-economic cell with a highly developed cult of ancestors and a family hearth [8]. The person who was intended to inherit by testament, became not just the owner of the family property, but also the testator's successor in terms of the sacred legal status in the family. Since the latter was "pater familias", after his death, his heir took this place, assuming the obligation to make sacrifices and extend hospitality, to patronize those who were under protection, the cult of the dead and blood vengeance, housekeeping. The specified succession has the personal legal status of the testator, the essence of which was reduced to the idea of inheritance as a legal fiction in the posthumous extension of power [9].

Hereditary legal succession has a number of distinctive features, namely: a) the basis of the transition is a complex set of facts, stipulated by the provisions of the succession law; b) transitional rights and obligations form a certain unity called the hereditary mass; c) the person acquiring the rights and obligations (heir) is the direct general (universal), but not partial (singular) legal successor of the deceased citizen [10]. As previously noted, the subject of universal legal succession is the entire set of rights and obligations of the legal successor, passing to its legal successor (legal successors). Thus, upon inheriting, the property of the testator is transferred to the heirs as a single whole, including proprietary rights and obligations, as well as personal (nonproprietary) rights associated with it $[6 ; 11]$.

\section{MATERIALS AND METHODS}

To achieve this purpose, the paper applies the laws and categories of dialectics (the unity of historical and logical, abstract and concrete, general and special, single and unique) and Aristotelian techniques (analysis and synthesis, induction and deduc- 
tion). The general methodological basis of the article was the dialectical method of cognition, which allows to analyse the research subject from different angles, but in unity with other legal phenomena, as well as with consideration of law enforcement practices.

In addition, the research process employs a set of approaches and methods of scientific cognition: multifactorial and contextual approaches, a systemic and structural method, a method of legal modelling, a dogmatic method, a comparative law method, a historical-law method, a systematic interpretation method, and legal and technical methods. Furthermore, means of hermeneutics were used, as the comparison always deals with other cultures, traditions, orders, texts, and without revealing their contents, their understanding also remains excluded.

Multifactorial and contextual approaches enabled the consideration of the sociocultural context of the formation and functioning of the institution of hereditary legal succession in the countries of the continental legal system and in Ukraine, its relationship with social, cultural and spiritual factors; the systemic and structural method ensured the consideration of the concepts of hereditary legal succession as relatively independent, sophisticated systems; the method of legal modelling allowed to recreate the structure of the mechanism of the functional effect of inheritance law on the basis of a statutory structure (legal regulation model) and a theoretical structure (model created by the power of abstraction); the dogmatic method allowed to determine the basic constructions of hereditary legal succession in the doctrine of foreign and domestic succession law, to identify their variety in the form of legal categories and legal models; comparative law method conditioned the search for similarities and differences, common, special and unique in the institute of hereditary legal succession in different legal systems; the historical-law method facilitated the identification of the prerequisites for the formation of the basic concepts of hereditary legal succession in foreign countries and in Ukraine; the systematic interpretation method and legal and technical method provided the opportunity to determine the true will of the legislator in the field of regulation and practical implementation of the analysed institution.

The use of the specified methods and theoretical and applied techniques facilitated the identification of the peculiarities of the formation of the institution of hereditary legal succession in the historical and theoretical aspect, the issues of its formation, development and reform, the formation of models and concepts of hereditary legal succession in modern Ukraine and the peculiarities of introducing the doctrine of hereditary legal succession of foreign countries into domestic civil law in the context of its improvement in the context of European integration of our state and transposition of legal provisions.

The empirical basis of the research performed within the scope of the article was composed of laws and other statutory acts of the countries of the continental system of law and Ukraine, judicial practice, revealing the problematics of implementing legal regulation of the research subject. 


\section{RESULTS AND DISCUSSION}

The universal nature of the hereditary legal succession in classical Roman law, which held the heir unlimitedly liable for the testator's debts, was based on the mystical idea that the legal identity of the deceased was embodied in the inheritance. At the same time, a distinctive feature of the hereditary legal succession is a one-time transfer (in a single act) to the legal successor of all rights and obligations that are part of the property of the predecessor. Thus, a characteristic feature of the hereditary legal succession is that the universal heir is the direct successor of the testator's property: the inheritance passes from the deceased to the heir not only immediately and simultaneously, but also directly from the testator [12].

It can be stated that universal legal succession in the succession law is fundamental, formed back in the law of Ancient Rome. Nevertheless, we shall point that the transfer of the entire set of rights and obligations of the testator to the heir is a general rule from which there are many exceptions (inheritance of certain objects of intellectual property, inheritance of an interest (share) in an entrepreneurial partnership, inheritance of securities, etc.). However, the legal nature of these exceptions, according to supporters of the concept of universality of hereditary legal succession, does not allow to attribute the succession of separate rights of the deceased to the hereditary legal succession, considering them not as hereditary, but as other legal relationships - legally binding. A typical example of this is the inheritance of testamentary deposit in a financial institution [13].

Thus, as per V.I. Serebrovsky's opinion, upon inheriting deposits in banking institutions, there is a contract in favour of a third party, and not a testamentary disposition, therefore there is no hereditary legal succession [2].

It is interesting that O.S. Ioffe considers these laws, supposedly inherent to succession, to be "specific methods or means of legal regulation that... condition direct and universal legal succession, which are understood to be the requirement of constructing inheritance as a universal and immediate succession, and interpret rules of the succession law in this regard" [11].

Universal legal succession is recognized as the main form of hereditary succession in the civil legislation of France [14], Japan [15] and other countries of the continental legal system [16]. A sign of the universality of hereditary legal succession found its reflection in foreign legal systems. Thus, in paragraph 1922 of Book 5 (Succession Law) of the German Civil Code of 1896, it is stated that after the death of a person, the inheritance passes to the heirs as a single whole [17].

With that, civilists that support the outlined concept of hereditary legal succession indicate that singular succession as a legal construct inherent in the civil law of Ukraine, in particular in legally binding obligations (assignment of debt, transfer of the right of claim) - does not occur in hereditary legal relations due to their polarity. When pointing out that, in the event of the death of their owner, the rights and obligations to certain civil law objects subordinate to the special legal regime are transferred to other persons, 
one should speak not about the occurrence of hereditary legal relations, but about other legally binding and proprietary relations regulated by corresponding provisions of civil legislation.

At the same time, the specified opinion is far from being the only one in the science of civil law. A proponent of a different scientific theory is, in particular, P.S. Nikityuk, who noted that legal succession in separate rights (a singular one) is not a distinctive feature of exclusively binding legal relations. A singular legal succession is also included in the subject of regulation of succession law and determines the occurrence of hereditary legal relations. This conclusion of P. S. Nikityuk is based on the fact that upon universal legal succession, as upon singular, the heir acquires an independent proprietary right of succession. It is noteworthy that in Roman private law the singular succession, along with universal, was also considered a form of the same phenomenonsuccession, and was part of the system of succession law [18-24].

Singular legal succession gained a foothold in the succession law of Ancient Rome due to implementation of such a legal structure as hereditas testamentaria, which was conditioned by the strengthening of legal succession elements in the proprietary status of the testator [12], as well as the weakening of the family-securing function of succession law [25].

Thus, in particular, the structure of the Civil Code of Ukraine, Book 6 "Succession Law", indicates the expansion of freedom of will, which entails a reduction in the rights of heirs (with the exception of persons entitled to a mandatory share in inheritance) who are the testator's family members. Furthermore, the appearance of the regulation in the Civil Code of Ukraine (Article 1223), according to which, the right to inherit belongs to the persons indicated in the testament, and only if there is no testament - to the heirs by law (persons who were in a relationship with the testator during his lifetime or were conceived during the life of the testator, but born after their death), indicates that the will of the testator is of paramount importance in succession, and not family relations ${ }^{1}$.

The foregoing allows us to talk about the absence of a tendency to strengthen the family in the institution of succession, which was characteristic of the succession law of the USSR period and is not a fundamental factor at the present time. This conclusion is justified by the fact that the purpose of succession is not to ensure the interests of the close relatives of the testator, as V.I. Serebrovsky points out [2], but, in the author's opinion, to transfer property or property rights, the preservation of civil-law relations, which the testator was a party to, with third parties, ensuring their stability in general. Therefore, in our opinion, the position of N.P. Aslanian does not quite correspond to the realities of legal and socio-economic life, in stating that the exclusion of the idea of strengthening the family, strengthening family and kinship ties from the succession

1 Civil Code of Ukraine: Law of Ukraine. (2003, January). Retrieved from https://zakon.rada.gov.ua/ laws/show/435-15 
law will complicate the justification of the existence of the very institution of inheritance in our society [25]. Thus, the succession law of Ukraine has its own objectives, which are not always aimed at strengthening family ties, although the existence of a family principle in it is not debatable [26].

Thus, the position of R.R. Weber, that the function material support of disabled family members in succession law has lost its significance and is not its most distinctive feature, being inherent in social security law related to public law, appears to be justified [27].

Granting a person the right to draw a will in favour of persons not included in the circle of heirs by law, as well as a possible reduction in the size of the mandatory share in inheritance (Article 1241 of the Civil Code of Ukraine) ${ }^{1}$, a special legal regime of sucession of certain types of property and proprietary rights, allow to point at the shift of emphasis in the methodology of building the science of civil law in matters of hereditary legal succession. Namely, this refers to restriction of the role of the family support function in the succession law and the development of the concept of singular legal succession in the succession law. Thus, an analysis of the current legislation of Ukraine displayed that it largely borrowed the legal models of the researched institution that were developed back in the era of Ancient Rome, implementing them in the national legal system.

Considering the issues of hereditary legal succession, P.S. Nikityuk concludes that the authors of the concept of universality of hereditary legal succession do not derive its main provisions the material basis of the succession law, and do not connect them with the economic nature of succession, personal or other property of citizens, with social purpose of succession in a socialist society, raising the question of whether the requirements of universality of hereditary legal succession correspond to the family nature of succession law, to the objective of securing the proprietary interests of the family, and finally, to the promotion of the family in carrying out its social functions [13].

Universality, immediacy, and other "properties" of hereditary legal succession derived from these two theses are presented, in fact, in the form of self-evident certain invariable principles inherent in any hereditary legal succession [28-31]. These postulates are submitted as the indisputable and self-evident basis of the substantive institution of succession and the procedure for registration of the right to inheritance [13].

Defending the position of the singular legal succession in the succession law, it should be noted that the current legislation of Ukraine, in particular, the succession law, provides examples far from solitary as to the allocation of individual objects of succession law from the general rules on succession. Such is, in particular, the inheritance of a share in a farm (agriculture) by members of the corresponding economy [32].

1 Civil Code of Ukraine: Law of Ukraine. (2003, January). Retrieved from https://zakon.rada.gov.ua/ laws/show/435-15 
Nevertheless, the above, as well as other cases of inconsistency of succession with the idea of universality (inheritance in copyright, inheritance of securities, inheritance of a contribution to a financial institution, an obligatory share in inheritance, etc.) are described in the science of civil law as an exception to the general rule on the universality of hereditary legal succession, as well as cases not characteristic of the succession law in general [2]. However, if we assume that this approach is correct, it is quite advisable to classify such objects of succession law in order to determine their legal regime on the one hand, and assign them to the provisions of obligation, property or succession law on the other hand.

If we adhere to the position of supporters of the concept of universality of hereditary legal succession, then we will inevitably come to the conclusion that the legal status of the specified objects is determined by the regulations of property law or the regulations of law of obligations, but not in any way by the succession law. With that, the transfer of rights to securities, as well as objects of intellectual property to third parties after the death of their owner is governed exclusively by the rules of property law. However, such conclusion is highly debatable, as proprietary relations determine the statics of civil relations, while the transfer of rights to securities is an indicator of the dynamics of civil-law relations. The regulation of specified objects by the provisions of law of obligation, however, indicates that securities can be a form of fixing obligations between the parties, which, in turn, is also incorrect, as the contract cannot be an object of civil law.

The above allows us to conclude that the legal succession of certain objects of civil law (securities, contributions to a financial institution, etc.) is either not subject to civil law regulation at all, or confirms that the singular nature of inheritance of civil law objects is inherent in the succession law.

Justifying the stated position, it should be noted that the scope and specific legal regime of these objects of civil law is such that it is possible to speak not so much about the exclusion of their rules of universality of hereditary legal succession, but about the principle of hereditary legal succession inherent not only to universality, but also to singularity in hereditary legal succession. In addition, the very fact of existence of the established procedure for the inheritance of a number of succession law objects that are subjected to a special legal regime, allows us to imply not an exception to the rules, as it assumes an unsystematic, one-time nature, but a part of the inheritance rule itself.

Upon consideration of the order of succession by testament, in our opinion, it should be pointed out that succession, contrary to the opinion of V.I. Serebrovsky [2], is not characterized by the principle of universality as a whole. This conclusion of the author follows from the analysis of the provisions of civil legislation of Ukraine.

Thus, in accordance with Articles 1235-1236 of the Civil Code of Ukraine, the testator has the right to independently appoint one or more persons as their heirs, regardless of the existence of family, kinship or other relations between them. Furthermore, the testator may, without indicating reasons, deprive any person from the number of 
heirs by law of the right to inherit. The testator has the right to cover the will with the rights and obligations that belong to him at the time the will is being drawn up, as well as those rights and obligations that may belong to them in the future. Moreover, the testator has the right to draw up a will regarding the entire inheritance or part thereof ${ }^{1}$.

In addition, in accordance with Articles 1237-1239 of the Civil Code of Ukraine, the testator has the right to establish a testamentary refusal to the legatee regarding the proprietary right or property that is or is not part of the inheritance transferred to the property, or by other proprietary right. Thus, upon inheriting by testament, the principle of unity of the hereditary mass and universality of the hereditary legal succession cannot be observed, as in this case the testator independently determines the amount of the hereditary mass transferred in the order of hereditary legal succession to a certain heir.

Upon conducting a comparative analysis of two concepts of hereditary legal succession, it should be noted that the most consistent understanding of the principle of universality of hereditary legal succession corresponds to the unlimited liability of heirs for the testator's debts $[13 ; 33]$. Nevertheless, the responsibility of the heirs is not an indispensable attribute of the universal legal succession, since the volume of this responsibility is directly proportional to the volume of the hereditary mass transferred to a particular person. The indicated conclusion is also reached by one of the founders of the concept of universality of hereditary legal succession, B.B. Cherepakhin, who claimed that the heir who accepted the inheritance is liable for the testator's debts within the actual cost of the inheritable property transferred to them [7].

The limitation of liability for the testator's debts was also recognized by V.N. Nikolsky as a derogation from the principle of universality of hereditary legal succession [34-35]. The considered provisions of the concept of universality and the singularity of hereditary legal succession, in their turn, indicate that the succession law is characterized by a singular nature.

Proceeding from the foregoing, it seems rather prudent to generalize the conceptual provisions in the context of a comprehensive analysis of doctrinal approaches and legal regulation of the researched institution:

Hereditary legal succession, namely, the transfer of the testator's rights to the heir, is based on the general principles of legal succession, however, it is distinguished by its originality. Discussions on the essence of the transfer of the rights and obligations of the testator to the heir failed to solve the multitude of issues of the theory of hereditary legal succession. Many points of the theory still remain debatable, moreover - and now you can observe a fundamentally different approach to identifying the essence and content of hereditary legal succession.

The performed analysis of the researched institution displayed that hereditary legal relations do not fit into the theory of legal relations and traditional views on its object,

1 Civil Code of Ukraine: Law of Ukraine. (2003, January). Retrieved from https://zakon.rada.gov.ua/ laws/show/435-15 
common in the legal literature. Moreover, the analysis of hereditary legal relations led to a different view on the object of legal relations and on the legal relationship itself.

Two approaches to the question of the nature of hereditary legal succession were formed in the doctrine of civil law.

According to the first one, upon inheritance, legal succession bears a universal nature. Proponents of the second point of view note that the singular legal succession is inherent to the succession law along with universal one.

The concept according to which the universal nature is inherent to the succession law along with the singular one is currently the most justified, which is conditioned by the consistent tendency of the succession law of Ukraine to expand the rights of subjects of hereditary legal relations, the allocation of objects from the hereditary mass, which feature a special legal regime for regulating their succession, and the tendency to weaken the family support functions of succession law.

Hereditary legal succession is a special type of legal succession in civil law and is characterized by the following features: a) it takes place only in the event of death of a person; b) it is embodied in proprietary and non-proprietary rights and obligations; c) transitional rights and obligations are dual in nature (universal and singular); d) as a result of the transfer of proprietary and non-proprietary rights and obligations in the order of hereditary legal succession, the legal relationship does not stop, but continues to exist in an amended form.

Hereditary legal relationship should not be considered solely as a relationship of universal legal succession of the testator's rights and obligations. A singular character is also inherent to it, along with universal legal succession.

The formation of the singular nature of hereditary legal succession, along with universal legal succession, as one of the features of hereditary legal succession is conditioned by the shift from the requirement of direct succession in the personal legal status of inheritance characteristic of the USSR period that did not recognize the legal and economic foundations of private property, to the requirement of direct transfer of property that currently corresponds to the concept of private property.

Determination of singular legal succession as means of transferring inheritance rights from the legal predecessor to the legal successor is conditioned by the following criteria: a) the specificity of the legal regime of certain types of property included in the estate; b) the socio-legal significance of the objects of succession law, transferred in the manner of a singular legal succession; c) the volumetric nature of the hereditary mass transferred in the order of a singular hereditary legal succession.

Universality and immediacy in inheritance is not a fundamental principle of Ukrainian succession law. The variety of the legal regimes of the hereditary mass objects serves as the justification of the necessity for further differentiation of both the principles of succession law and individual objects of inheritance, depending on their legal regime. 
The analysis of hereditary legal succession indicates the differentiation of the hereditary mass depending on the scope of the rights transferred and the specifics of the legal regime of the transferred property, in the order of hereditary legal succession, of the procedural order for registration of inheritance rights.

Without a doubt, a singular legal succession in succession law is typical for hereditas testamentaria, and upon inheritance by law, only in legally binding and proprietary relations, the objects of which are subjected to a special legal regime (the right to a mandatory share in inheritance - Art. 1241 of the Civil Code of Ukraine, the establishment of servitude in a testament - Art. 1246 of the Civil Code of Ukraine, testament with a condition - Art. 1242 of the Civil Code of Ukraine, testamentary refusal Art. 1237 of the Civil Code of Ukraine, inheritance of the right to deposit in a bank, financial institution - Art. 1228 of the Civil Code of Ukraine) ${ }^{1}$.

On the other hand, the universal nature of hereditary legal succession is inherent, as a rule, to succession by law, as well as in legally binding and proprietary relations, objects of succession law, in which they are subjected to the general legal regime (inheritance of the right to compensation for losses, moral damage and payment of the penalty - Art. 1230 of the Civil Code of Ukraine, inheritance of the right to receive insurance payments, insurance compensation - Art. 1229 of the Civil Code of Ukraine, inheritance of the land title - Art. 1225 of the Civil Code of Ukraine, the right to receive wages, pensions, scholarships, alimony, other social benefits belonging to the testator Art. 1227 of the Civil Code of Ukraine, inheritance of the obligation to compensate property damage (losses), as well as moral damage caused by the testator - Art. 1231 of the Civil Code of Ukraine).

The conducted analysis of doctrinal approaches to the researched institution and law enforcement practices provided an opportunity to formulate the following issues in the field of hereditary legal succession in the civil law of Ukraine, which require gradual and balanced solution:

- the necessity of unification and legalisation of a single approach to the nature of hereditary legal succession, the formation of a single conceptual approach with elements of existing theories;

- the essence of the institution of hereditary legal succession and its content remains understudied from a holistic perspective;

- the lack of a unified approach to the procedure for satisfying the claims of creditors upon recognition of the inheritance by the deceased, in particular their turn, the scope of the hereditary mass;

- the circle of heirs is determined unequally by law and by testament;

- various requirements for the form of the testament are established;

- various systems for the distribution of hereditary property exist;

1 Civil Code of Ukraine: Law of Ukraine. (2003, January). Retrieved from https://zakon.rada.gov.ua/ laws/show/435-15 
- questions arise more frequently in the field of legal regulation of hereditary legal succession with a foreign element;

- issues of succession of various types of inheritance objects remain unsolved;

- the variability of approaches to hereditary legal succession of corporate rights in the context of new laws of the current legislation of Ukraine and others.

This list of issues is not exhaustive and is subject to an expanded interpretation, as well as to be supplemented, with consideration of modern transformation of civil-law relations. However, the solution of the outlined issues will become possible only by consolidating the efforts of representatives of doctrine and practices in order to unify, update, and, as a result, to qualitatively reform the legal regulation of the institution of hereditary legal succession in Ukraine in the context of the positive experience of other states and its gradual testing at the national level.

\section{CONCLUSIONS}

Inheritance is traditionally considered to be one of the oldest and most stable institutions in the law of any state. The regulation of inheritance by the regulations of national substantive law is ensured by many historically established legal institutions that differ in the degree of detail of regulation, the specific composition of institutions and some other parameters at the national levels of different countries. In the course of the research, it was found that most of the basic principles of inheritance enshrined in the legislation of Ukraine and countries of continental law, were introduced back in the times of Roman private law. However, the development of public relations is gradually modifying the economic relations, which, in turn, affects proprietary relations, the variability of which necessitates the development and improvement of the provisions governing the transfer of rights from one person to another, both as general rules and as provisions of succession law as special legal regulation. In turn, the legal succession is characterized by the fact that there is a legal dependence of the rights and obligations of its predecessor. Upon legal succession, a new entity in legal relations takes the place of the initial one, and the rights received by it remain identical to the rights of the initial entity. This process can be considered as a replacement in the static legal relationship of one subject by another, and as a transition from one subject to another of all elements of a legal relationship, which allows the new subject to "fit" into the legal relationship that previously existed.

Today, two trends have formed and are operating on the territory of the state - the singular and universal hereditary legal succession. Representatives of each approach emphasize the prudence of choosing only one universal approach to the investigated legal relations. The research of the main features of hereditary legal succession led to the conclusion that these legal relations do not fit under the theory of legal relations commonly used in legal literature and traditional views on its object, which allowed to 
state the necessity of combining the existing approaches into a single doctrinally substantiated concept of the essence of the institution of hereditary legal succession, which will become the object of further scientific research.

It can be stated that representatives of national scientific schools have not yet formed a unified approach to the essence of the institution of hereditary legal succession, which characterizes its complexity and produces various issues of legal regulation related to this phenomenon and the practice of its enforcement. So, as a result of a comprehensive research, the main issues in the field of hereditary legal succession in civil law of Ukraine were formulated. The above list requires its vector resolution by means of combining scientific and practical approaches in order to qualitatively reform the legal regulation of the institution of hereditary legal succession in Ukraine in the context of the best practices of other states and its gradual testing at the national level.

\section{REFERENCES}

[1] Bernad Mainar, R. (2019). Reflections on the conservation or suppression of the compulsory share in the future reform of successions of the civil code. Actualidad Juridica Iberoamericana, 10, 374-413.

[2] Serebrovsky, V.I. (2003). Selected works on inheritance and insurance law. Moscow: Statut.

[3] Kirillova, E.A., Suslikov, V.N., Bogdan, V.V., Baybarin, A.A., \& Sheveleva, S.V. (2015). Mobile real estate: Legal status and succession principles. Journal of Advanced Research in Law and Economics, 6(1), 96-103.

[4] Ioffe, O.S. (1965). Soviet civil law. Moscow: Leningrad State University Publishing House.

[5] Guliyev, K. (2017). Local custom in international law: Something in between general custom and treaty. International Community Law Review, 19(1), 47-67.

[6] Pfeiffer, M. (2016). Legal certainty and predictability in international succession law. Journal of Private International Law, 12(3), 566-586.

[7] Lerdo De Tejada, M. E. (2019). Equality by reason of filiation and succession law. Actualidad Juridica Iberoamericana, 10, 336-365.

[8] Tajani, F., \& Morano, P. (2018). A model for the elaboration of fair divisional projects in inheritance disputes. Property Management, 36(2), 186-202.

[9] Pirim, C. Z. (2018). State succession to international responsibility: A critical analysis of the modern succession theory based on the general principles of law. Czech Yearbook of Public and Private International Law, 9, 111-129.

[10] Carrillo Pozo, L.F. (2018). The European regulation 650/2012 and the change of paradigm of the succession law. Boletin Mexicano De Derecho Comparado, 50(151), 51-83.

[11] Ioffe, O.S. (1975). Soviet civil law. Moscow: Yuridicheskaya literatura.

[12] Rodríguez González, A. M. (2018). The accessory character of guarantees in roman law. are the present independent guarantees newly formed legal concepts? Revista De Estudios Historico-Juridicos, 40, 47-69.

[13] Viarengo, I. (2016). Choice of law agreements in property regimes, divorce, and succession: Stress-testing the new EU regulations. ERA Forum, 17(4), 543-554.

[14] Whittaker, S. (2019). Unfair terms in commercial contracts and the two laws of competition: French law and english law contrasted. Oxford Journal of Legal Studies, 39(2), 404-434

[15] Vagatsuma, S., \& Ariizumi, T. (1983). Japanese Civil Law. Moscow: Progress. 
[16] Kamyshansky, V.P., Rudenko, E.Y., Kolominetz, E.A., \& Osadchenko, E.O. (2019). Regarding the issue of the essence of legal treatment and the possibility of granting legal status to a robot in civil law. Studies in Computational Intelligence, 826, 299-306.

[17] Sarvarian, A. (2016). Codifying the law of state succession: A futile endeavour? European Journal of International Law, 27(3), 789-812.

[18] Marongiu Buonaiuti, F. (2016). The EU succession regulation and third country courts. Journal of Private International Law, 12(3), 545-565.

[19] North, M. (2018). History of law and economic history: Institutional factors in the economy of the holy Roman empire. Zeitschrift Der Savigny-Stiftung Fur Rechtsgeschichte, Germanistische Abteilung, 135(1), 401-407.

[20] Salogubova, E., \& Zenkov, A. (2018). Roman law's influence on russian civil law and procedure. Russian Law Journal, 6(2), 118-133..

[21] Viglione, F. (2018). The influence of fundamental rights on the law of succession. European Business Law Review, 29(5), 773-789.

[22] Jordan, D.P. (2018). Roman history, then and now. History and Theory, 57(1), 137-148.

[23] Beinoravičius, D. (2018). Globalization and law. Logos (Lithuania), 94, 23-32.

[24] Załucki, M. (2018). Attempts to harmonize the inheritance law in Europe: past, present, and future. Iowa Law Review, 103(5), 2317-2338.

[25] Hammad, M. (2017). Succession. Semiotica, 2017(214), 351-372.

[26] Kono, K., Ito, Y., Aoyama, A., Kamoda, H., \& Babaguchi, N. (2009). Matrix-based algorithm for integrating inheritance relations of access rights for policy generation. Journal of Information Processing, 17, 318-327.

[27] Weber, R.R. (1965). Correlation of civil and family law. Issues of civil and labor legislation of Soviet Latvia. Riga: Russian State University.

[28] Drozd, O.Y. (2017). Civil service pattern in germany and ukraine: A comparative aspect. Journal of Advanced Research in Law and Economics, 8(5), 1503-1507.

[29] Wilson, E.A. (2016). Restrictive national laws affecting human rights civil society organizations: A legal analysis. Journal of Human Rights Practice, 8(3), 329-357.

[30] Kalaur, I., \& Fedorchenko, N. (2018). Normative and individual regulator in the mechanism of regulation of legal relations under transfer of property in use. Transformations in Business and Economics, 17(1), 38-49.

[31] Zarosylo, V., Korostashyvets, Y., Maksymova, L., \& Nechyporuk, S. (2018). Features of the legal protection of property rights in Ukraine and the European Union. Naukovyi Visnyk Natsionalnoho Hirnychoho Universytetu, 6, 124-130.

[32] Martens, D. (2018). Mapping variation of civil society involvement in EU trade agreements: A CSI index. European Foreign Affairs Review, 23(1), 41-62.

[33] Chaban, N., Knodt, M., \& Headley, J. (2018). Introduction: The EU and its eastern neighbours-perceptions and strategic dialogue in the region. European Foreign Affairs Review, 23, 1-22.

[34] Nikolsky, V.N. (1871). About inheritance highlights. Moscow: Nauka.

\section{Anatoly V. Kostruba}

Doctor of Law, Associate Professor, Professor

Department of Civil Law

Vasyl Stefanyk Precarpathian National University

76018, 57 Shevchenko Str., Ivano-Frankivsk, Ukraine 
Suggested Citation: Kostruba, A.V. (2019). Hereditary legal succession in the civil law of Ukraine: problematic and theoretical aspect. Journal of the National Academy of Legal Sciences of Ukraine, 26 (3), 135-149.

Submitted: $14 / 05 / 2019$

Revised: 08/07/2019

Accepted: 19/08/2019 